\title{
Etyka służby w grupach dyspozycyjnych — socjologiczne konteksty
}

https://doi.org/10.19195/2083-7763.10.16

\section{Abstrakt}

Etyka poszczególnych grup dyspozycyjnych stanowi istotne narzędzie kształtujące zachowania funkcjonariuszy tych grup i ma wpływ na prawidłowe funkcjonowanie każdej organizacji. W artykule poddano analizie rolę etyki zawodowej w codziennej służbie funkcjonariuszy policji. Rozważania w tym zakresie podjęte zostały w odniesieniu do kultury samej organizacji, jaką jest policja, jak również do dwóch obszarów działania jej funkcjonariuszy - to jest w ramach służby i poza nią. Celem opracowania jest wykazanie zależności pomiędzy oceną zachowań funkcjonariuszy policji przez pryzmat stosowania zasad etyki zawodowej a postrzeganiem tej instytucji w społeczeństwie i budowaniem zaufania do jej przedstawicieli.

Słowa kluczowe: etyka zawodowa, policja, grupy dyspozycyjne

Policjant, wstępując do służby, rozpoczyna swoją nową drogę życia od złożenia ślubowania, które odbywa się bardzo uroczyście w obecności najbliższych i sztandaru jako symbolu tożsamości i honoru danej jednostki. Następnie nowoprzyjęty funkcjonariusz podpisuje własnoręcznie formularz ślubowania, który zostaje włączony do jego akt osobowych. Złożona rota ślubowania zobowiązuje funkcjonariuszy tej formacji do kilku najbardziej elementarnych zasad postępowania, $\mathrm{w}$ tym między innymi do przestrzegania zasad etyki zawodowej ${ }^{1}$. Zatem już na samym

${ }^{1}$ Zgodnie z art. 27 ust. 1 ustawy z 6 kwietnia 1990 r. o Policji (tekst jedn. Dz.U. z 2016 r. poz. 1782): przed podjęciem służby policjant składa ślubowanie według następującej roty: „Ja, obywatel Rzeczypospolitej Polskiej, świadom podejmowanych obowiązków policjanta, ślubuję: służyć wiernie Narodowi, chronić ustanowiony Konstytucją Rzeczypospolitej Polskiej porządek prawny, 
początku służby osoba rozpoczynająca karierę policyjną winna mieć świadomość wagi i rangi etyki, o której jest zobowiązana pamiętać przy realizacji codziennych obowiązków zawodowych, jak również w życiu prywatnym.

Realizując zadania służbowe, policjant często napotyka sytuacje przysparzające trudności w ocenie moralnej, zmuszony jest podejmować decyzje w przypadkach, kiedy prawo i procedury nie dają jednoznacznych rozwiązań. Nadto wymaga się od niego, aby jego zachowanie poza służbą - w życiu prywatnym i rodzinnym opierało się również na zasadach etycznych i było zgodne $\mathrm{z}$ wizerunkiem strażnika praworządności. Można zatem stwierdzić, że policjant funkcjonuje na pograniczu dwóch światów: tego „dobrego", który sam powinien reprezentować, i tego „złego”, który ma obowiązek zwalczać. Zdarza się jednak, że staje przed niełatwym wyborem, kiedy to przepis prawa, zgodnie $\mathrm{z}$ którym winien postąpić, $\mathrm{w}$ jego ocenie stoi w sprzeczności z normą moralną, poczuciem sprawiedliwości lub sumieniem.

Etyka zawodowa, niezależnie jakiej grupy pracowniczej dotyczy, ma charakter interdyscyplinarny - łączy w sobie bowiem elementy etyki ogólnej, akceptowanej przez ogół społeczeństwa, z elementami specyficznymi określonego zawodu. Jej odrębność może wynikać jedynie z hierarchicznego układu wartości wynikającego na przykład ze specyfiki służby policyjnej ${ }^{2}$. Zawód policjanta wymaga niewątpliwie wyjątkowej odpowiedzialności i sumienności, a funkcjonariusze tej formacji, służąc obywatelom, poddają się jednocześnie społecznej ocenie ${ }^{3}$.

Podejmując próby rozważań o etyce Policji, należy wyróżnić etykę w postępowaniu funkcjonariuszy przy wykonywaniu przez nich czynności służbowych, etykę $w$ relacjach interpersonalnych oraz etykę $w$ zachowaniu policjanta będącego poza służbą. Te wyszczególnione składowe tworzą szeroko rozumianą etykę zawodu funkcjonariusza Policji.

\section{Specyfika zawodu policjanta jako podstawa wyodrębnienia etyki zawodowej}

Przedstawiciele wielu zawodów kierują się formalnymi i niepisanymi zasadami, a także normami postępowania, które regulują jego funkcjonowanie. Bez tych reguł sprawne działanie $\mathrm{w}$ żadnej grupie zawodowej nie jest możliwe, ponieważ ich brak skutkowałby chaosem i samowolą przy realizacji obowiązków. Wszelkie

strzec bezpieczeństwa Państwa i jego obywateli, nawet z narażeniem życia. Wykonując powierzone mi zadania, ślubuję pilnie przestrzegać prawa, dochować wierności konstytucyjnym organom Rzeczypospolitej Polskiej, przestrzegać dyscypliny służbowej oraz wykonywać rozkazy i polecenia przełożonych. Ślubuję strzec tajemnic związanych ze służbą, honoru, godności i dobrego imienia służby oraz przestrzegać zasad etyki zawodowej”.

${ }^{2}$ E. Legowicz, Problemy moralne w pracyoperacyjnej i dochodzeniowo-śledczejpolicji, [w:] Wybrane zagadnienia etyki policji, red. J. Czerniakiewicz, Szczytno 1995, s. 53.

3 Zob. J. Kunikowski, Wartość w życiu codziennym i służbie, „Policja 997” 1, 2016, s. 18-19. 
kodeksy etyczne zawierające zbiory zasad i wartości wyznaczają standardy postępowania, ukierunkowują reprezentantów określonego zawodu w sytuacjach podejmowania przez nich decyzji związanych z wykonywanymi obowiązkami zawodowymi, szczególnie wówczas, gdy stoją oni przed trudnymi i niejednoznacznymi moralnie wyborami. Reguły te mają również w konsekwencji ograniczać zachowania, które w jakikolwiek sposób mogłyby narazić na szwank dobre imię przedstawicieli danej profesji oraz całego środowiska zawodowego.

Policja jako organ władzy państwowej i samorządowej powołany do ochrony bezpieczeństwa i porządku publicznego stanowi jeden z podstawowych elementów systemu, bez którego państwo nie utrzymałoby stabilności i ładu społecznego. Stawia to tę instytucję wysoko w hierarchii innych zawodów (w tym również zawodów tzw. zaufania publicznego), a tym samym podnosi znacząco poprzeczkę co do wymagań etycznych stawianych jej funkcjonariuszom. Społeczne oczekiwania wobec funkcjonariuszy policji sprawiają, że wymóg określonej postawy moralnej stanowi bardzo istotny czynnik definiujący służbę w tej formacji. Policjanci, egzekwując przestrzeganie prawa, niewątpliwie sami winni być wzorem do naśladowania i autorytetem służb mundurowych ${ }^{4}$. W związku z tym, że stróże prawa $\mathrm{w}$ codziennej służbie mają do czynienia przede wszystkim z człowiekiem posiadającym niezbywalną godność, specyfika tego zawodu predestynuje go do posiadania własnej etyki zawodowej $j^{5}$.

W zarządzeniu nr 805 Komendanta Głównego Policji z 31 grudnia 2003 r. "Zasady etyki zawodowej policjanta" (stanowiący załącznik do ustawy o Policji z 6 kwietnia 1990 roku) sformułowane zostały 24 zasady, tak zwane swoiste kanony opisujące szczegółowo zachowania etyczne funkcjonariusza policji. Wymienione zarządzenie nie zawiera znamion zachowań uznawanych za przewinienia dyscyplinarne, lecz pewne wzorce, których funkcjonariusz powinien przestrzegać i których naruszenie może skutkować odpowiedzialnością dyscyplinarną ${ }^{6}$. Wczytując się w ten zbiór zasad etycznych, odnajdujemy w nich gamę reguł określających pożądane postawy funkcjonariuszy, które można podzielić na trzy płaszczyzny, to jest zasady odnoszące się do ludzi jako ogółu, zasady stosowane w relacjach przełożony-policjant i zasady opisujące relacje międzyludzkie w organizacji.

W służbie policyjnej fundamentalną zasadą przyświecającą wykonywaniu zadań służbowych jest ochrona godności człowieka i jego konstytucyjnych praw

\footnotetext{
${ }^{4}$ Według słownika socjologicznego autorytet to osoba lub instytucja obdarzona ogólnym uznaniem i ciesząca się powszechnym szacunkiem, zob. K. Olechnicki, P. Załęcki, Słownik socjologiczny, Toruń 2002, s. 25.

${ }^{5} \mathrm{Na}$ specyfikę zawodu jako uzasadnienie etyki zawodowej policjanta wskazano w Zasadach etyki zawodowej policjanta w $\$ 1$ pkt 1 „Zasady etyki zawodowej policjanta wynikają z ogólnych wartości i norm moralnych uwzględniających specyfikę zawodu policjanta", wprowadzonych w życie zarządzeniem nr 805/2003 Komendanta Głównego Policji (Dz.U. KGP 2004 nr 1 poz. 3).

${ }^{6}$ Zob. wyrok Wojewódzkiego Sądu Administracyjnego w Krakowie z 28 września 2016 r., sygn. IIISA/Kr 339/16.
} 
oraz wolności. Sposób wykonywania tych czynności przez policjantów w odniesieniu do obywateli przekłada się bezpośrednio na wizerunek społeczny tej instytucji, a relacje interpersonalne wewnątrz samej instytucji mają bezpośredni wpływ na kształtowanie klimatu pracy, a przez to na efektywność wykonywanych zadań 7 .

Szczególną rolę w kształtowaniu pożądanych zachowań funkcjonariuszy policji należy przypisać postawom etycznym prezentowanym przez przełożonych. Ich postępowanie, zarówno wewnątrz organizacji, jak i w przypadkach reprezentowania formacji na zewnątrz, ma kapitalne znaczenie dla jej społecznego odbioru. Z jednej strony buduje to wewnętrzną siłę organizacji w zakresie potrzebnych autorytetów zawodowych i wzorów postępowania, z drugiej zaś kształtuje zewnętrzną o niej opinię. Zwierzchnik winien bowiem być wzorem, inspiracją i zachętą, a zarazem osobą, do której podwładny może zwrócić się z każdą sprawą. To przełożony odpowiedzialny jest za kontrolowanie podległych mu policjantów, dbanie o przestrzeganie określonych zasad, sprawiedliwe traktowanie i wspieranie rozwoju pracowników. Nie jest jednak możliwe, by postępowanie przełożonego zawsze było zgodne z punktami etyki zawodowej. Jak każdy człowiek ulega on chwilowym emocjom, szczególnie w sytuacjach stresujących, a nadto nie jest wolny od zwykłych ludzkich odczuć, jakimi są na przykład darzenie większą sympatią niektórych pracowników i większy dystans do innych ${ }^{8}$.

Nie ulega jednocześnie wątpliwości, że nieetyczne zachowania stróżów prawa stanowią istotny problem społeczny. Wiele z takich zachowań nigdy nie ujrzało i nie ujrzy światła dziennego, a opinia publiczna nie będzie świadoma, że określone sytuacje w ogóle mają miejsce ${ }^{9}$. Niektóre z nich są oczywiście ujawniane i nagłaśniane $\mathrm{w}$ mediach, co jest następstwem prowadzonych postępowań dyscyplinarnych wobec policjantów. Informowanie społeczeństwa o nieetycznym zachowaniu funkcjonariuszy policji pełni dwie podstawowe funkcje: piętnującą osoby, które dopuściły się złamania zasad moralnych, oraz informacyjną, mającą na celu wyostrzenie uwagi społeczeństwa i reagowanie na wszelkie zjawiska związane $\mathrm{z}$ brakiem etyki zawodowej ${ }^{10}$.

Własne doświadczanie i obserwacja pozwala na stwierdzenie, że dla części funkcjonariuszy policji termin „etyka” to jedynie przedmiot, który był wykładany oraz z którego byli następnie egzaminowani podczas kursów czy w trakcie innych

${ }^{7}$ E. Wiszowaty, Etyka Policji. Między prawem, moralnością i skutecznością, Warszawa 2011, s. 88.

${ }^{8}$ A. Pawłowski, Etyka przełożonego policyjnego - próba zestawienia głównych problemów, [w:] Etyka w zarządzaniu policja, red. A. Letkiewicz, Szczytno 2011, s. 55 n.

9 Jak trafnie ujęły to Monika Suchojad i Aneta Biernat-Guzdkiewicz, skargi kierowane na funkcjonariuszy zazwyczaj kwestionują ich zachowania, nie dotyczą natomiast ewentualnej nieznajomości przepisów czy ich niewłaściwego zastosowania, zob. M. Suchojad, A. Biernat-Guzdkiewicz, Trening etyczny Policji polskiej, „Bezpieczeństwo. Teoria i Praktyka” 3-4, 2010, s. 109.

${ }^{10}$ M. Żuk, Miejsce etyki zawodowej w stużbie polskiego policjanta, „Górnośląskie Studia Socjologiczne. Seria Nowa" 4, 2013, s. 176. 
form dokształcania zawodowego. Jest to dla nich zatem wyłącznie „zbiór 24 zasad", formalnie przyjętych w związku ze wstąpieniem do służby, które nie znajdują zastosowania w codziennej praktyce zawodowej.

\section{Etyka w postępowaniu funkcjonariuszy przy wykonywaniu czynności służbowych}

Czynności operacyjno-rozpoznawcze ${ }^{11}$ i dochodzeniowo-śledcze, a także czynności porządkowo-administracyjne to główne formy realizacji ustawowych zadań nałożonych na policję, które opierają się na swoistych nakazach i zakazach prawnych oraz moralnych.

Znaczna część problemów natury moralnej wiąże się ze sferą niejawną pracy policji określaną jako „praca operacyjna”. Jakość tych czynności i ich zgodność z obowiązującymi zasadami w znacznym stopniu zależy od postawy moralnej funkcjonariusza, a przede wszystkim od jego uczciwości ${ }^{12}$. Sama nazwa „operacyjne" powoduje, że pewne czynności są powszechnie uważane za nielegalne, a co za tym idzie - nieetyczne $\mathrm{z}$ samego założenia. W przeświadczeniu części społeczeństwa ten rodzaj służby jest szczególnie podejrzany moralnie, wobec tego człowiek żyjący zgodnie z zasadami prawa i etyki nie powinien mieć $\mathrm{z}$ nim do czynienia ${ }^{13}$. Nie ulega wątpliwości, że pod względem etycznym działania operacyjne są czynnościami często kontrowersyjnymi. Należy jednak pamiętać, że ich utajony charakter (jak inwigilacja czy obserwacja) przyczyniają się wielokrotnie do ochrony praw człowieka, jego dóbr osobistych czy praw majątkowych. Rozstrzygając ten konflikt, posłużyć można się takimi wyznacznikami, jak „mniejsze zło” czy szeroko rozumiany „stan wyższej konieczności” przy założeniu, że podejmowane działania ściśle mieszczą się w granicach prawa i mają na celu zapewnienie społeczeństwu poczucia bezpieczeństwa ${ }^{14}$.

Za stosowaniem środków i metod pracy operacyjnej przemawia jednakże wiele argumentów. Przede wszystkim podkreślić należy, że działania te - jeśli oczywiście mieszczą się w granicach prawa i podejmowane są przez osoby do tego umocowane - w znacznej mierze przyczyniają się do ujawnienia czynów zabronionych,

${ }^{11}$ Działania operacyjno-rozpoznawcze policji to metody zbierania informacji i dowodów poza procesem karnym w celu zapobiegania i zwalczania przestępczości oraz innych prawnie określanych negatywnych zjawisk społecznych. Metody te obejmują stosowanie utajonych środków i czynności: podsłuch, kontrole korespondencji, obserwacja osób i obiektów, wywiad operacyjny, analiza anonimów, korzystanie z usług tajnych informatorów, działania policjantów pod przykryciem, podstęp; szerzej zob. D. Szumiło-Kulczycka, Czynności operacyjno-rozpoznawcze i ich relacje do procesu karnego, Warszawa 2012.

12 Praca operacyjna bywa też określana jako „etyczne oszustwo”.

13 E. Wiszowaty, op. cit., s. 197-198.

${ }^{14}$ Więcej na ten temat zob. G. Kędzierska, Aspekt etyczny działań kryminalistycznych, [w:] Policja. Etyka. Kościół, red. E. Wiszowaty, G. Kędzierska, W. Pływaczewski, Szczytno 2002, s. 151. 
ustalenia ich sprawców, a w konsekwencji prowadzą do ukarania winnych ${ }^{15}$. Stąd czasami pojawia się pewna rozbieżność między nakazami etycznymi i taktykami kryminalistycznymi a przepisami prawa. Wszędzie tam, gdzie przepisy prawa nie określają wyczerpująco zasad i metod postępowania przy realizacji czynności operacyjno-rozpoznawczych oraz tam, gdzie pojawia się wspomniany rozdźwięk między nakazami prawa a wskazaniami teorii i praktyki kryminalistycznej, funkcjonariusz policji musi wypracować rozwiązanie kompromisowe. Z jednej strony rozwiązanie takie nie może naruszać norm prawnych, a z drugiej strony winno być zgodne z postulatami etyki zawodowej. Wyboru tego musi dokonać sam policjant i zależy to często od jego własnej, wypracowanej postawy moralnej, od własnego rozumienia pojęcia dobra i zła ${ }^{16}$.

Innego rodzaju moralne usprawiedliwienie tajności policyjnych działań operacyjno-rozpoznawczych można dostrzec, utożsamiając pracę policji z pewnym rodzajem walki. W każdym pojedynku są przeciwnicy, którzy dążą do zdobycia przewagi, a jednym z elementów taktyki walki jest nieujawnienie swoich zamiarów oraz poufne zdobywanie informacji o rywalu. Przeciwnikiem policji jest świat przestępczy i dlatego formacja ta otrzymuje od społeczeństwa moralne wsparcie, kredyt zaufania i upoważnienie do jego zwalczania z zastosowaniem niejednokrotnie takich środków, które same w sobie mogłyby zostać uznane za etycznie wątpliwe $^{17}$. Niemniej jednak działalność operacyjna policji realizowana w warunkach niejawności w pewnym zakresie może pozostawać w konflikcie nie tylko z ogólnie uznawanymi postulatami etyki, lecz także z podstawowymi prawami obywateli.

Czynności procesowe, w przeciwieństwie do operacyjnych, policjant wykonuje jawnie, opierając się, co do zasady, na przepisach prawa. Jego praca jest weryfikowalna, widoczna, dająca się skontrolować i ocenić.

W policyjnej etyce zawodowej, przy realizacji zarówno czynności niejawnych, jak i jawnych, do rangi fundamentalnych dyrektyw moralnych podniesione zostały praworządność i poszanowanie godności człowieka. Te dwie cechy określają miejsce policjanta w państwie i społeczeństwie, wyznaczają powinności, a także przypominają o służebnej roli policji wobec prawa firmowanego przez państwo oraz obywatela - członka społeczeństwa. Specyfika pracy operacyjnej i dochodzeniowo-śledczej jak w soczewce skupia w sobie wymienione dyrektywy moralne i nakazuje pamiętać o nich podczas wykonywania wszystkich tych czynności ${ }^{18}$.

Wymagania praworządności wynikają ze szczególnego stosunku funkcjonariuszy prowadzących postępowania przygotowawcze do prawa. Ze względu na charakter wykonywanych obowiązków powinni oni znać obowiązujące przepisy w celu ich właściwego zastosowania. W praktyce jednak, z uwagi na niedostatki w systemie

15 Zob. B. Hołyst, Kryminologia, Warszawa 2000, s. 56.

${ }^{16}$ E. Legowicz, op. cit., s. 55.

${ }_{17}$ M. Stefański, Aktualne zagadnienia i dylematy etyki zawodowej policjanta, „Policyjny Biuletyn Szkoleniowy" 3, 1998, s. 36-37.

18 E. Legowicz, op. cit., s. 58. 
szkolenia policyjnego, niewystarczającą znajomość przepisów prawa przez funkcjonariuszy, a także ciagłe i liczne zmiany tych przepisów, kompetencje policjantów są niewystarczające, aby dokonywać prawnych ocen zdarzeń, z którymi mają do czynienia.

Poszanowanie godności człowieka w zawodzie policyjnym jest zadaniem priorytetowym. Trudność w stosowaniu się do tej zasady w każdej sytuacji polega na tym, że funkcjonariusz często działa $\mathrm{w}$ warunkach ekstremalnych, a w konsekwencji jest wyposażony w środki przymusu bezpośredniego i ma uprawnienie do zatrzymywania osób. Nie zwalnia go to jednak z obowiązku szanowania godności obywatela, wobec którego podejmowane są te działania. Jest to zadanie niejednokrotnie bardzo trudne, ponieważ funkcjonariusze spotykają się przy realizacji czynności służbowych nie tylko z oporem czy wulgarnością osób, których te czynności bezpośrednio dotyczą, lecz także z zachowaniami daleko bardziej niebezpiecznymi, narażającymi ich na bezpośrednie niebezpieczeństwo utraty zdrowia czy życia. Policja nie jest ich sojusznikiem, gdyż dąży do zapewnienia bezpieczeństwa i porządku publicznego, a operacyjnie czy procesowo zmierza do zebrania materiału dowodowego, który może te osoby obciążać. Poszanowanie godności „przeciwnika”, nawet jeżeli on sam nie szanuje godności drugiego człowieka, jest rzeczą trudną, ale niezbędną we wszystkich działaniach policji. Prawo nie rozstrzyga tych kwestii wyczerpująco i w tym przypadku dużą rolę odgrywają zasady etyki zawodowej, które pozwalają na ocenę, czy określone czynności i sposób ich realizacji są dopuszczalne i znajdują uzasadnienie okolicznościami danej sytuacji.

Należy zwrócić uwagę między innymi na sposób, w jaki funkcjonariusz zwraca się do osoby, wobec której podejmuje interwencję. Wprawdzie w niektórych sytuacjach postawa takiego człowieka czy stan, w jakim się znajduje, może determinować konieczność bardziej stanowczego, a nawet protekcjonalnego potraktowania, jednakże nie może to być związane z naruszeniem godności tej osoby i przejawiać się w wulgarnym czy pogardliwym odnoszeniu się do niej podczas podejmowanych czynności. Co więcej, nawet wobec osób, które nie wydają się ze względu na swoje zachowanie „zasługiwać” na zwykłe odruchy ludzkiej życzliwości, należy okazać zrozumienie, gdy chodzi o potrzebę zapalenia papierosa czy nawet porozmawiania dla rozładowania napiętej sytuacji.

Innym stałym elementem składającym się na problematykę etyki zawodowej policjanta jest kwestia kontaktów policjantów z pokrzywdzonymi. W kontaktach tych szczególnie oczekuje się, aby funkcjonariusz wykazał się życzliwością, uprzejmością i taktem, niejednokrotnie dyskrecją i szacunkiem wobec osoby dotkniętej bezprawnym zachowaniem innego podmiotu. Często pierwszy kontakt pokrzywdzonego z przedstawicielem organu ścigania determinuje dalsze zachowanie ofiary przestępstwa i może zapobiegać zjawisku wtórnej wiktymizacji ${ }^{19}$.

${ }^{19}$ Więcej na temat wzoru społecznego policjanta zob. J. Maciejewski, Grupy dyspozycyjne. Analiza socjologiczna, Wrocław 2014, s. 126 n. 
Należy dodać, że nie zawsze czynności funkcjonariuszy Policji dotyczą zdarzeń noszących znamiona przestępstwa czy wykroczenia. Niejednokrotnie ich zadaniem jest wyłącznie udzielenie informacji, wskazówek i pomocy obywatelom w sytuacji problematycznej. Niezależnie czy są to przypadki zaginionych dzieci, osób poszkodowanych w katastrofach, wypadkach drogowych, klęskach żywiołowych - zawsze pojawia się etyczny problem, jak ma się zachować policjant wobec tych osób ${ }^{20}$.

Rozpatrując aspekty etyczne przy wykonywaniu czynności służbowych przez funkcjonariuszy, należy zastanowić się nad legitymizacją oraz granicami stosowania środków przymusu bezpośredniego, w tym broni palnej. Ustawodawca, nakładając na Policję określone zadania, wymaga od funkcjonariuszy skutecznego działania w każdej zaistniałej sytuacji, nawet wówczas gdy ma do czynienia z brutalną agresją, której ma obowiązek się przeciwstawić. Policjant, otrzymując środki przymusu bezpośredniego, w pewnej mierze godzi się na sprzeniewierzenie się fundamentalnym prawom, jakim jest prawo do poszanowania godności czy prawo do życia. W codziennej służbie, w zaistniałej sytuacji, policjant, używając broni palnej czy innego środka przymusu bezpośredniego wobec drugiej osoby w granicach prawa, nie popełnia przestępstwa w rozumieniu algorytmów czy norm stanowionych. Społeczne uzasadnienie użycia środków przymusu bezpośredniego, w tym broni palnej, jest większe wobec przestępców, innych osób zachowujących się agresywnie czy pseudokibiców, ale w przypadku podejmowanych interwencji wobec osób przejawiających w swoim zachowaniu zaburzenia psychiczne, będących pod wpływem alkoholu czy narkotyków, czynności policjanta muszą być ukierunkowane nie tylko na działania zgodne z przepisami, ale na poszanowanie ich praw bez względu na stan zdrowia.

Problem etycznej legitymizacji środków przymusu bezpośredniego będących na wyposażeniu funkcjonariuszy policji należy oceniać w szerokim kontekście. Policjant nie działa jako osoba prywatna i we własnym imieniu, ale z upoważnienia instytucji, jaką jest państwo, chociaż odpowiedzialność ponosi osobiście. Stosując te środki, policjant musi wyważyć proporcje pomiędzy indywidualnym zachowaniem i zamiarem sprawcy a interesem dobra wspólnego, jakim jest zapewnienie bezpieczeństwa czy to sobie, czy innym osobom. Nie zawsze przy podjętej interwencji jest to możliwe, gdyż czynności te wykonywane są w dużym napięciu nerwowym czy pod presją czasu, a skutki użycia środków przymusu bezpośredniego często mają charakter nieodwracalny.

${ }^{20}$ Zob. A. Pawłowski, Etyka polskiej policji. Próba zestawienia głównych problemów, [w:] Policja $w$ Polsce. Stan obecny i perspektywy, t. 1, red. A. Szymaniak, W. Ciepiela, Poznań 2007, s. 252-259. 


\section{Etyka w relacjach interpersonalnych}

W Polsce po 1990 roku kobietom otworzyła się droga do coraz szerszego dostępu do służby w Policji. Warunki przyjęcia do tej formacji zawarte zostały w ustawie o Policji z 6 kwietnia 1990 roku, zgodnie z którą „służbę w Policji może pełnić obywatel polski o nieposzlakowanej opinii, niekarany, korzystający z pełni praw publicznych, posiadający co najmniej średnie wykształcenie oraz zdolność fizyczną i psychiczną do służby w formacjach uzbrojonych podległych szczególnej dyscyplinie służbowej”. Wskazują one zatem na równe prawa przedstawicieli obojga płci w dostępie do tej służby, jeżeli kryteria te zostaną spełnione. Nadto zwiększenie liczby kobiet w szeregach Policji należy wiązać za społecznym wymiarem tej służby, wyrażającym się w kontaktach z ludźmi oraz swoistym poczuciu misji, jaką stanowi walka z przestępczością. Etycznie uzasadnione jest zatem dążenie do takiego ukształtowania zasad dostępu do służby w tej formacji, aby dawały równe szanse zarówno kobietom, jak i mężczyznom. Za nieetyczne należy uznać więc tworzenie sztucznych barier w tym zakresie, na przykład poprzez stawianie dodatkowych wymagań kandydatkom w postaci wyjątkowej sprawności fizycznej czy też określonych wysokich parametrów wzrostu ${ }^{21}$.

Panujące jeszcze stereotypowe myślenie o funkcjonariuszce, która godzi dwie role - niewątpliwie niezmiernie absorbującą czasowo i emocjonalnie rolę zawodową oraz rolę żony, partnerki czy matki, daje często podstawy do dyskryminacji kobiet-policjantek przez przełożonych czy kolegów. Ujawnia się to niekiedy wyrażanym niezadowoleniem przełożonych, którzy wychodzą z przekonania, że policjantki w przyszłości będą korzystały z długotrwałych zwolnień macierzyńskich czy wychowawczych, co wiąże się z koniecznością rozdzielenia ich zadań służbowych, dodatkowych służb czy dyżurów na pozostałych podwładnych. To z kolei wywołuje różnego rodzaju nieetyczne postawy kolegów wobec osoby, której absencja spowodowana jest tego typu sytuacjami, co wyraża się w ignorowaniu jej, izolowaniu od społeczności zawodowej czy też kierowaniu wobec niej obraźliwych komentarzy. Takie zachowania są bardziej zauważalne w małych jednostkach policji, gdzie liczba etatów jest niewielka lub w komórkach organizacyjnych, w których znaczny procent stanowią kobiety.

Oprócz zasygnalizowanych problemów, bardzo poważnym zagrożeniem w procesie integracji mężczyzn i kobiet w Policji jest molestowanie seksualne czy mobbing. Często zjawiska te przenikają się i jedno jest następstwem drugiego. Niekiedy „zaczepki erotyczne” traktowane są w zależności od sytuacji czy to przez funkcjonariuszki, czy przez funkcjonariuszy jako potwierdzenie ich atrakcyjności czy wyrażenie zainteresowania, a tym samym są w pełni akceptowane. Niemniej jednak

${ }^{21}$ Zob. więcej D. Hryszkiewicz, J. Kubiak, Kobiety w Policji. Teoria i praktyka, Szczytno 2016, s. $50 \mathrm{n}$. 
w tym kontekście warto zaznaczyć, że mniej prowokacyjne formy seksualnego „nagabywania", takie jak niestosowne żarty, aluzje czy umieszczenia erotycznych zdjęć, na przykład w postaci plakatów czy kalendarzy w miejscach wspólnego przebywania policjantek i policjantów, mogą być traktowane jako prowokowanie, a na pewno jako nieetyczne zachowanie tych, którzy dopuszczają się tego typu praktyk. Bardziej drastyczne zachowania, takie jak nakłanianie do stosunku seksualnego wbrew woli, naruszanie nietykalności osobistej poprzez dotykanie intymnych części ciała są już zachowaniami mogącymi wypełniać znamiona przestępstw ${ }^{22}$.

Inną formą nieetycznych zachowań w relacjach interpersonalnych w Policji jest mobbing. Nie omawiając szerzej tego zagadnienia, warto wyodrębnić dwie formy zjawiska mobbingu: „bossing” - kiedy przełożony poniża czy szykanuje jednego lub kilku członków podległego mu personelu oraz „staffing” - gdy to podwładni lekceważą i znieważają swojego przełożonego. Z uwagi na policyjną strukturę organizacyjną opartą na hierarchiczności działającą na zasadzie poleceń służbowych i rozkazów, najczęstszą spotykaną formą mobbingu w tej formacji jest „bossing”. Niejednokrotnie środki masowego przekazu ujawniają przypadki szykanowania podwładnych przez przełożonych. Szukając przyczyn zachowań mobbingowych przełożonych, wskazać można na niewłaściwy nabór osób na stanowiska kierownicze, które nie mając autorytetu wśród współpracowników lub mając różnego rodzaju kompleksy, w pełnionej funkcji upatrują możliwość swoistej nobilitacji i źródła uznania dla swojej osoby. Często są to osoby, którym w życiu rodzinnym nie układa się, a swoje frustracje przenoszą na relacje zawodowe, wyładowując się na podwładnych. Jak podaje Piotr Pytlakowski, jednym $\mathrm{z}$ istotniejszych powodów mobbingu wobec podwładnych $\mathrm{w}$ policji są również szeroko pojęte statystyki. Naciski wywierane na przełożonych przez ich zwierzchników, nakierowane na osiągnięcie określonych wyników przekładają się na relacje z podwładnymi i skutkują stawianiem przed nimi celów, często niemożliwych do zrealizowania, co z kolei prowadzi do zastraszania czy szykanowania ${ }^{23}$.

Nieetyczne zachowanie $\mathrm{w}$ kontaktach interpersonalnych to również różne przejawy koleżeńskiej zazdrości. Niejednokrotnie szybszy awans, przyznana premia, lepsze osiągnięcia, bardziej bezpośrednie kontakty z przełożonym czy nawet korzystniejsza sytuacja materialna rodziny poczytywane są za formy separowania się od ogółu społeczności, jaką tworzy grupa funkcjonariuszy danej jednostki, co daje często sfrustrowanym tymi faktami współpracownikom swoiste przyzwolenie na nieetyczne zachowania wobec kolegów.

22 E. Wiszowaty, op. cit., s. 144-149.

23 Zob. P. Pytlakowski, Policyjna fala, „Polityka” 16.01.2010, s. 22-23. 


\section{Etyka poza służbą}

Wśród społeczności policyjnej funkcjonuje przekonanie, że policjantem jest się zarówno w czasie służby, jak i poza nią. Oczekiwania takie wyrażane są również przez obywateli, którzy chcieliby, aby funkcjonariusze prezentowali nienaganną postawę moralną, również w życiu prywatnym, a przede wszystkim gotowi byli stanąć w obronie ludzi czy mienia również w sytuacjach niezwiązanych z wykonywaniem przez nich obowiązków zawodowych. W związku z takim podejściem od stróża prawa zawsze wymaga się postępowania zgodnego z prawem oraz z zasadami etyki zawodowej. Bardzo często w środowisku lokalnym, gdzie żyje i funkcjonuje policjant, postrzegany jest on jak osoba, która może doradzić w sprawach rodzinnych czy sąsiedzkich konfliktów, ocenić określone zachowanie pod względem zgodności z przepisami prawa czy też pomóc w innych, codziennych sprawach osobom, które nie radzą sobie same w kontaktach $z$ urzędami i skomplikowanymi procedurami związanymi z załatwianiem określonych spraw. Taki wizerunek funkcjonariusza istnieje szczególnie w małych społecznościach, w tym przede wszystkim wiejskich, gdzie policjant ma stosunkowo wysoki status społeczny, ale jednocześnie jest dobrze znany członkom lokalnej wspólnoty i w związku z tym zazwyczaj obdarzany przez nich dużym zaufaniem.

Zdarzają się jednak przypadki, gdy funkcjonariusz poza służbą sprzeniewierza się zasadom etyki zawodowej, a nawet postępuje sprzecznie z przepisami prawa, popełniając wykroczenia czy przestępstwa. Przede wszystkim przestępstwa umyślne, ścigane z oskarżenia publicznego, których sprawcami są policjanci, rodzić mogą radykalne postawy społeczne wobec całej formacji, która ustawowo stoi na straży prawa.

Chyba najczęściej wymienianym "grzechem” funkcjonariuszy jest stosowanie przemocy wobec członków rodziny, szczególnie gdy w czasie wolnym od pracy nadużywają oni alkoholu czy sięgają po środki odurzające, tłumacząc to koniecznością odreagowania stresu czy frustracji związanych ze służbą. Niejednokrotnie takim funkcjonariuszom zakładane są tak zwane niebieskie karty. Przyczyn takich przypadków z całą pewnością upatrywać należy w stresie, jaki towarzyszy im przy wykonywaniu czynności służbowych. Sytuacje takie niewątpliwie mają negatywny wpływ na wizerunek Policji jako formacji powołanej do ścigania sprawców przestępstw. Kluczowe znaczenie dla eliminowania tego typu patologicznych zachowań mają podejmowane wszelkiego rodzaju działania profilaktyczne przez wszystkie jednostki i komórki organizacyjne Policji. Główną rolę w tym procesie powinni odgrywać bezpośredni przełożeni funkcjonariuszy, ponieważ mają największą siłę oddziaływania na podwładnych, możliwość rozpoznawania i reagowania na symptomy takich zachowań, ustalania ich przyczyn i podejmowania działań zaradczych.

Odnotowuje się także przypadki używania przez funkcjonariuszy legitymacji służbowych do celów prywatnych czy też powoływania się na przynależność 
do formacji przy załatwianiu spraw osobistych. Ma to na przykład miejsce podczas kontroli drogowych, gdy chcąc uniknąć odpowiedzialności za popełnione wykroczenie, wykorzystują oni swój status zawodowy i powołują się na solidarność zawodową.

Zdarza się również, że policjant wykorzystuje do celów prywatnych informacje uzyskane w związku z wykonywaniem obowiązków służbowych czy uzyskuje informacje do tych celów przy użyciu służbowych metod.

Niewątpliwie każdy przejaw niezgodnego z prawem czy nawet tylko nieetycznego zachowania funkcjonariusza poza służbą skutkuje negatywnym odbiorem społecznym jego osoby, jak również grupy zawodowej, jakiej jest członkiem. Dla osób, które żyją w najbliższym otoczeniu takiego policjanta, te sytuacje są szczególnie bulwersujące - często jest on bowiem tym, do którego jako do pierwszego zwróciłyby się o pomoc czy którego wskazówki uwzględniłyby w trudnej sytuacji.

\section{Postępowania dyscyplinarne jako reakcja na naruszenie zasad etyki zawodowej}

Objęcie policjantów odpowiedzialnością dyscyplinarną uzasadnione jest społeczną rolą tej formacji, charakterem powierzonych zadań i kompetencjami oraz związane z działalnością Policji publicznym zaufaniem. Odpowiedzialność ta ma również służyć przeciwdziałaniu zachowaniom, które mogłyby pozbawić policjantów wiarygodności w oczach opinii publicznej, zwłaszcza że wiele uprawnień pozwala im na ingerowanie w sferę obywatelskich wolności i praw ${ }^{24}$. Można zatem stwierdzić, że odpowiedzialność dyscyplinarna, jak sama nazwa wskazuje, ma nie tylko być formą represji wobec tych, którzy dopuścili się określonych deliktów, ale zagrożenie nią ma również oddziaływać prewencyjnie na potencjalnych sprawców naruszających przepisy prawa czy zasady etyki zawodowej.

Zgodnie z art. 132 ust. 1 ustawy o Policji funkcjonariusz odpowiada dyscyplinarnie wyłącznie za popełnienie deliktu dyscyplinarnego polegającego na naruszeniu dyscypliny służbowej lub nieprzestrzeganiu zasad etyki zawodowej.

Pociągnięcie policjanta do odpowiedzialności dyscyplinarnej za naruszenie zasad etyki zawodowej może nastąpić wyłącznie, jeżeli zaistnieje funkcjonalny związek popełnionego czynu nieetycznego $\mathrm{z}$ wykonywaniem zawodu. Związek ten nie wynika jedynie $\mathrm{z}$ faktu popełnienia czynu w trakcie realizacji obowiązków służbowych, w czasie służby lub w miejscu jej pełnienia. Policjant może dopuścić się tego typu przewinienia także poza służbą, nie wykonując czynności służbowych,

${ }^{24}$ Zob. wyrok Trybunału Konstytucyjnego z 8 października 2002 r., sygn. K 36/00. 
ponieważ ma obowiązek przestrzegania praworządności i nie jest od tego zwolniony nawet w czasie wolnym od służby ${ }^{25}$.

$\mathrm{Na}$ podstawie danych uzyskanych z Komendy Głównej Policji na wykresie przedstawiono zestawienie liczbowe zdarzeń związanych z nieprzestrzeganiem etyki zawodowej i naruszeniem dyscypliny służbowej przez funkcjonariuszy ujawnionych na przełomie kolejnych 15 lat. Należy zaznaczyć, że przedstawione dane to jedynie przypadki ujawnione, które były przedmiotem prowadzonych postępowań dyscyplinarnych. Rzeczywista liczba wszystkich przypadków łamania zasad etyki zawodowej przez policjantów nie jest jednak znana.

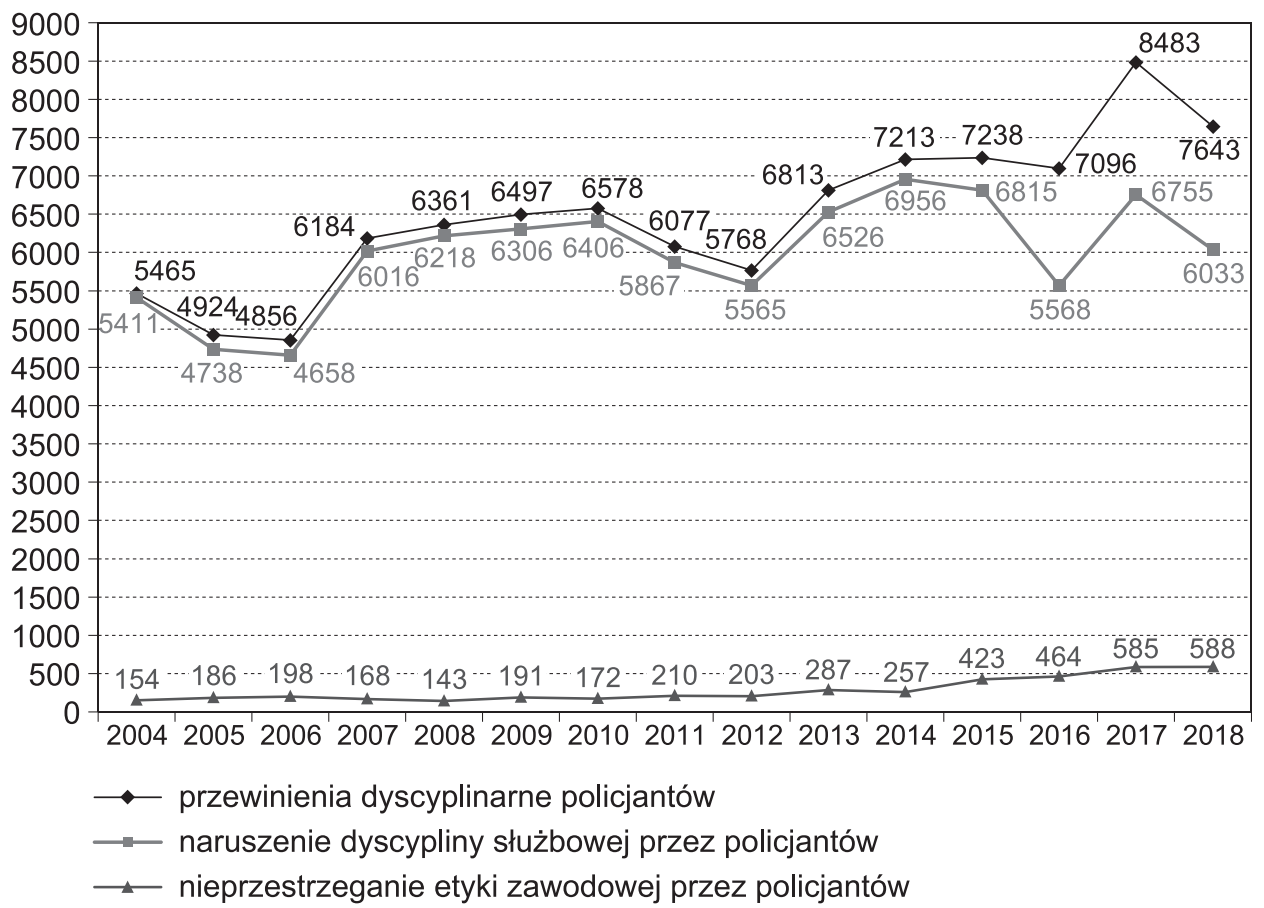

Wykres 1. Dane dotyczące postępowań dyscyplinarnych prowadzonych wobec funkcjonariuszy Policji w latach 2004-2018.

Źródło: dane Komendy Głównej Policji.

Na podstawie powyższego zestawienia można stwierdzić, że w okresie piętnastu lat liczba ujawnionych przypadków nieprzestrzegania przez funkcjonariuszy zasad etyki zawodowej wzrostowi z odnotowanymi niewielkimi wahaniami. Jeżeli jednak weźmiemy pod uwagę liczbę i rodzaj czynności podejmowanych przez

${ }^{25}$ Zob. wyrok Wojewódzkiego Sądu Administracyjnego w Łodzi z 10 lutego 2015 r., sygn. IIISA/Łd 1038/14.

Forum Socjologiczne 10, 2020

(C) for this edition by CNS 
funkcjonariuszy każdego dnia na przestrzeni jednego roku ${ }^{26}$, to $\mathrm{z}$ jednej strony skala naruszeń etyki zawodowej przez policjantów jawi się jako niewielka, z drugiej zaś przypadki łamania etyki - niestety - zostały odnotowane.

Własna obserwacja pozwala na stwierdzenie, że funkcjonariusze, wykonując czynności służbowe, coraz częściej dopuszczają się czynów nieetycznych, ale postawy takie nie zawsze bulwersują ich środowisko zawodowe, $\mathrm{w}$ tym również przełożonych, a tym samym nie zawsze spotykają się ze stosowną rekcją z ich strony. Dotyczy to przede wszystkim drobnych zachowań, których stopień społecznej szkodliwości nie jest znaczny, ale których powtarzalność może w konsekwencji skutkować niewłaściwym odbiorem społecznym tej formacji. Tak dzieje się w przypadku nadużywania wulgaryzmów, lekceważącego stosunku do osób, wobec których podejmują czynności służbowe, czy też nadmiernego spożywania alkoholu poza pracą. Tego typu zachowania ujawniane są przede wszystkim na skutek skarg składanych przez obywateli, przy czym właściwa postawa kolegów czy przełożonych mogłaby ograniczyć częstotliwość tego typu zjawisk czy nawet je zmarginalizować.

\section{Wnioski}

Postępowanie zgodne z zasadami etyki zawodowej jest zawsze wsparciem dla policjanta, wyznacznikiem najważniejszych zasad, którymi funkcjonariusz powinien się kierować w życiu zawodowym oraz prywatnym. To właśnie etyka zawodowa winna być dla niego wyznacznikiem właściwego zachowania i wskazówką przy podejmowaniu decyzji związanych z codziennym funkcjonowaniem, zarówno w ramach służby, jak i poza nią. Jeśli funkcjonariusz nie może odwołać się do zasad etyki zawodowej, wówczas powinien postąpić zgodnie z normami powszechnie akceptowanymi w społeczeństwie, cały czas mając na uwadze dobre imię Policji i ochronę praworządności ${ }^{27}$.

Sprostanie tym wyzwaniom nie zawsze jest możliwe, a funkcjonariusz, jak każdy człowiek, skłonny bywa do ulegania różnym „pokusom”. Jego niewłaściwe zachowanie rzuca wówczas cień nie tylko na niego samego, ale przede wszystkim

\footnotetext{
${ }^{26}$ Jak wynika z informacji przekazanych przez Zastępcę Komendanta Głównego Policji, nadinsp. Jana Lacha, każdego dnia na przestrzeni 2017 roku tylko policjanci służby prewencyjnej przeprowadzili 16330 interwencji, zatrzymali 397 sprawców przestępstw na gorącym uczynku, wylegitymowali 59161 osób, 48858 przebadali stan trzeźwości, skontrolowali 21047 uczestników ruchu drogowego, pełnili 4112 służb na drodze, 14645 służb patrolowych i obchodowych i zrealizowali 385 konwojów. Zob. Odprawy stużbowe. Podsumowanie i plany, „Policja” 3, 2018, s. 6.

27 Współzależność różnych systemów norm, w szczególności norm prawnych, moralnych, obyczajowych i religijnych jest przedmiotem rozważań teoretyków nauki o państwie i prawie, zob. S. Wronkowska, Z. Ziembiński, Zarys teorii prawa, Poznań 1997, s. 81-94.
} 
na całą formację, utrudniając niekiedy innym policjantom wykonywanie ich ustawowych obowiązków.

Należy jednak pamiętać, że sformułowanie zasad etycznych nie jest „cudownym środkiem" rozwiązującym wszystkie problemy, ale dzięki nim funkcjonariusz ma szansę rozstrzygnąć trudne kwestie, zwłaszcza w przypadku pojawiających się wątpliwości co do moralnej oceny siebie wobec przełożonych, podwładnych, kolegów w mundurze i całego środowiska policyjnego ${ }^{28}$.

Niemniej jednak samej etyce zawodowej w systemie szkolenia funkcjonariuszy Policji poświęca się zbyt mało czasu, sprowadzając nauczanie w tym zakresie w zasadzie wyłącznie do teoretycznego przytoczenia treści regulującego jej zasady zarządzenia. Wydaje się natomiast, że codzienna służba funkcjonariuszy daje wiele możliwości odwołania się do przykładów praktycznych, co pozwoliłoby na skonfrontowanie tych zasad z konkretnymi, problematycznymi sytuacjami i stanowiłoby impuls do dyskusji nad możliwymi rozwiązaniami dylematów pojawiających się w życiu policyjnym.

\section{Bibliografia}

Odprawy służbowe. Podsumowanie i plany, „Policja” 3, 2018, s. 6.

Hołyst B., Kryminologia, Warszawa 2000.

Hryszkiewicz D., Kubiak J., Kobiety w Policji. Teoria i praktyka, Szczytno 2016.

Kędzierska G., Aspekt etyczny działań kryminalistycznych, [w:] Policja. Etyka. Kościót, red. E. Wiszowaty, G. Kędzierska, W. Pływaczewski, Szczytno 2002.

Kunikowski J., Wartość w życiu codziennym i służbie, „Policja 997” 2016, nr 1, s. 18-19.

Legowicz E., Problemy moralne w pracy operacyjnej i dochodzeniowo-śledczej policji, [w:] Wybrane zagadnienia etyki policji, red. J. Czerniakiewicz, Szczytno 1995.

Maciejewski J., Grupy dyspozycyjne. Analiza socjologiczna, Wrocław 2014.

Olechnicki K., Załęcki P., Słownik socjologiczny, Toruń 2002.

Pawłowski A., Etyka polskiej policji. Próba zestawienia głównych problemów, [w:] Policja w Polsce. Stan obecny i perspektywy, t. I, red. A. Szymaniak, W. Ciepiela, Poznań 2007.

Pawłowski A., Etyka przełożonego policyjnego - próba zestawienia głównych problemów, [w:] Etyka w zarządzaniu policją, red. A. Letkiewicz, Szczytno 2011.

Pietkiewicz E., Materiały pokonferencyjne „Etyka zawodowa policjanta”, red. M. Róg, Szczytno 1998.

Pytlakowski P., Policyjna fala, „Polityka”, 16 .01.2010.

Stefański M., Aktualne zagadnienia i dylematy etyki zawodowej policjanta, „Policyjny Biuletyn Szkoleniowy" 1998, nr 3.

Suchojad M., Biernat-Guzdkiewicz A., Trening etyczny Policji polskiej, „Bezpieczeństwo. Teoria i Praktyka" 2010, nr 3-4.

Szumiło-Kulczycka D., Czynności operacyjno-rozpoznawcze i ich relacje do procesu karnego, Warszawa 2012.

Wiszowaty E., Etyka Policji. Między prawem, moralnością i skutecznością, Warszawa 2011.

Wronkowska S., Ziembiński Z., Zarys teorii prawa, Poznań 1997.

${ }^{28}$ E. Pietkiewicz, Materiały pokonferencyjne „Etyka zawodowa policjanta”, red. M. Róg, Szczytno 1998, s. 11.

Forum Socjologiczne 10, 2020

(C) for this edition by CNS 
Zarządzenie nr 805/2003 Komendanta Głównego Policji (Dz.Urz. KGP 2004 nr 1 poz. 3).

Żuk M., Miejsce etyki zawodowej w stużbie polskiego policjanta, „Górnośląskie Studia Socjologiczne.

Seria Nowa", 4, 2013.

\section{Wykaz orzecznictwa}

Wyrok Trybunału Konstytucyjnego z 8 października 2002 r., sygn. K 36/00.

Wyrok Wojewódzkiego Sądu Administracyjnego w Łodzi z 10 lutego 2015 r., sygn. IIISA/Łd 1038/14.

Wyrok Wojewódzkiego Sądu Administracyjnego w Krakowie z 28 września 2016 r., sygn. IIISA/Kr $339 / 16$.

\section{The ethics of dispositional groups - a sociological context}

\section{Summary}

The ethics of particular dispositional groups is an essential instrument which forms the behaviour of their members and has an influence on the proper functioning of each organisation. In the article the author analyses the role of professional ethics in everyday police work. Considerations in this field have been taken with reference to the culture of the police as an organisation. The author looked into two areas of police activity - as part of their service and outside of it. The purpose of the study is to show the relationship between and evaluation of police officers' behaviour, through the prism of the ethics of obedience and the perception of this institution in society affecting the trust put in its representatives.

Keywords: professional ethics, police, dispositional groups 